\title{
SŁAWOMIR ŁOTYSZ
}

https://orcid.org/0000-0003-4426-6401

L. and A. Birkenmajer Institute

for the History of Science

of the Polish Academy of Sciences, Warsaw

\section{DESERT MOULD: WITOLD ODRZYWOLSKI AND HIS WORK ON CRUDE PENICILLIN IN A MILITARY HOSPITAL IN THE MIDDLE EAST IN $1944^{*}$}

Abstract: The author analyses the activities of Witold Odrzywolski, who in 1944 was the first Pole to produce penicillin, in a military hospital in the Middle East. The paper contextualizes this achievement in a broad array of the scientific, medical, military and political determinants of the era.

Keyw ords: penicillin, Second World War, military healthcare, medicine, Polish Second Corps.

\section{Introduction}

In April 1945 the British Medical Journal (hereafter BMJ) published a short note about a 'Professor Odrzywolski' who produced penicillin in a Polish war hospital in the Middle East. ${ }^{1}$ According to the note, the Polish doctor had undergone special training in antibiotic production in England and even conducted his own experiments in his field laboratory. This modest note is one of the very few references to the achievements of Major Witold Odrzywolski (1904-71), a physician serving with the Second Polish Corps. Two months later the same piece of information, with some additional details, was released by the Biuletyn Prasowy (Press Bulletin) published in London by the Światpol Polish Press Agency. ${ }^{2}$

${ }^{*}$ The article has been written thanks to the support of the National Science Centre (grant no. 2014/13/B/HS3/04951).

${ }^{1}$ British Medical Journal, 14 April 1945, p. 510.

2 'Penicylina na piasku', Biuletyn Prasowy, 22 April 1945, pp. 5-6. The tone of the note is fairly exalted, and its authors uses the penicillin to demonstrate that Poles 'are the equals of any nation in any field'. The main message of the Polish note is similar to that of the British original, but the former contains more information clearly indicating 
The BMJ note, although brief and not without errors, touches upon matters that are quite important from the point of view of research into the history of medical sciences. For example, it states quite clearly that in the spring of 1945 the Polish hospital was the only military outpost in the region producing penicillin, suggesting at the same time that it did so in quantities sufficient to supply the medication to other, not only Polish hospitals of the Allied forces operating in the Middle East. ${ }^{3}$ This piece of information requires an explanation for several reasons. Odrzywolski was not the first man to produce penicillin in field conditions in the region and to use it in its crude form in the treatment of patients. A pioneer in this respect was Colonel Robert Pulvertaft from the Pathological Laboratory of the 15th Scottish General Hospital in Cairo, who used the broth he obtained to supplement the meagre supplies of the purified antibiotic from England since March 1943. ${ }^{4}$ From a medical point of view such an activity made sense until mid-1944 at the latest, when thanks to a substantial increase of production in British, Canadian and above all American factories the supply of the drug to Allied troops improved considerably. In the spring of 1945, when the BMJ wrote about Odrzywolski's work, so much penicillin was being produced that the United States lifted the ban on its use in civilian healthcare. Moreover, in laboratory conditions one culture of Penicillium notatum was enough to produce an amount of the antibiotic sufficient only for a few experimental treatments. Thus a question arises: Why did Odrzywolski produce penicillin at a time when it had become fairly easily accessible in military healthcare in the Middle East? ${ }^{5}$

Other questions prompted by this brief note concern the origin of the Penicillium notatum strain used by Odrzywolski in his experiments. According to the BMJ, the Poles received two phials with mycelium spores from Howard Florey himself. This happened allegedly in May 1944, yet according those participating in the events, Odrzywolski began to work on crude penicillin already in April, using for the purpose two strains of Penicillium which the Poles had got from Jewish researchers in Palestine, when their hospital had stopped there on its way from Iraq to Egypt earlier that year.

that the Światpol Agency had its own source of information. It was not infallible, however. Its interpretation of some facts contradicts that of primary sources.

${ }^{3}$ British Medical Journal, 14 April 1945, p. 510.

${ }^{4}$ Pulvertaft's work has been described in detail by Harold Wyatt, a microbiologist from the University of Leeds, see 'Robert Pulvertaft's Use of Crude Penicillin in Cairo', Medical History, 1990, 34, pp. 320-26.

${ }^{5}$ We do not know why the BMJ attached so much significance to this matter. Answering the question would be easier, it we knew the name of the person who passed this piece of information to the journal. But the note is not even signed. 
We can find just as many inaccuracies in Polish accounts of Odrzywolski's work, beginning with the Światpol Agency's note and ending with the doctor's obituary published in Rocznik Polskiego Towarzystwa Naukowego na Obczyźnie, an annual publication of a London-based Polish scholarly society. ${ }^{6}$ The inaccuracies concern primarily the chronology of the events. For example, according to his obituary, Odrzywolski went to England for his training in 1943, while in fact he was there in late 1944 and early 1945. Since in this period progress in penicillin research was very dynamic, such a shift of the date by a year may lead to largely mistaken conclusions concerning the significance of Odrzywolski's work. An assessment of his work requires not only that these inconsistencies be explained, but also that the Polish doctor's work be presented in a broader medical, scientific, military and political context of the period. What is thus essential is an analysis of the state of penicillin research at the time, including analysis of experiments with the production and use of the crude form of the drug. This cannot be done without referring to the question of the availability of the drug in the Allied forces' military healthcare in the Middle East. What is also important is the medical dimension of Odrzywolski's work, that is how much active substance he was able to obtain, how many patients were successfully treated with it and finally - what lessons were learned and what impact this experience had on the development of medical and pharmaceutical sciences.

The first scholar in Polish historiography to mention Odrzywolski's activities was Tadeusz Brzeziński, although he limited himself to quoting substantial fragments of the memoirs of Odrzywolski's laboratory assistant, without trying to present a broader context of the events she described. The history of the first experience of the Second Polish Corps doctors with penicillin has already been examined by Aleksander Rutkiewicz, although in his study Rutkiewicz focuses mainly on the clinical applications of the new drug. ${ }^{8}$ A detailed survey of the British, Italian and Polish archives carried out for the purpose of this study has enabled the present author to reveal hitherto unknown sources of crucial significance to the reconstruction of the work of this unjustly forgotten Polish doctor. ${ }^{9}$

${ }^{6}$ S.O., 'śp. doc. dr Witold Marian Odrzywolski', Rocznik Polskiego Towarzystwa Naukowego na Obczyźnie, 22, 1971-72, pp. 24-25.

7 Tadeusz Brzeziński, Służba zdrowia Polskich Sił Zbrojnych na Zachodzie 1939-1946, Wrocław, 2008, pp. 136-37.

${ }^{8}$ Aleksander Rutkiewicz, 'Wprowadzenie penicyliny do lecznictwa w Polskich Siłach Zbrojnych na Zachodzie’, Lekarz Wojskowy, 89, 2011, 2, pp. 161-68.

${ }^{9}$ Suffice it to say that following the author's request, Odrzywolski's file at The National Archives in London was declassified nearly half a century earlier than usual. 
The present article makes a contribution to the study of the local and global contexts of the history of the first antibiotic, as it expands the existing body of knowledge concerning early attempts to obtain the drug outside the countries which were leaders in scientific and technological developments. Neither Odrzywolski's experiments nor the work on obtaining penicillin carried out in Palestine in the mid-1940s have been described in the literature before.

\section{Purified or Crude?}

In 1940 a team of researchers headed by Howard Florey and Ernst Chain, and working at the Sir William Dunn School of Pathology, University of Oxford, confirmed Alexander Fleming's discovery, made twelve years before, of the bacteriostatic properties of the Penicillium notatum fermentation broth. Penicillin salts, a product of the Penicillium notatum metabolism, dissolved in the fluid were effective at stopping the growth of most gram positive organisms, including primarily Staphylococcus aureus, which caused purulent infections and a whole range of other diseases. Developing an industrial method for recovering a pure penicillin salt from the broth proved very problematic and initially the quantities of the drug obtained were minuscule. Access to it was restricted only to military doctors: American doctors in military hospitals on the Pacific islands and British doctors in the Middle East. ${ }^{10}$ In practice these were clinical trials and not regular treatments.

Purified penicillin was not used on a broader scale until the Sicilian campaign in the summer of 1943. When the campaign ended, a conference was organized in Tripoli to sum up the experience gained. ${ }^{11}$ During the conference, the participants of which included - in addition to the heads of the British medical services - Florey, doctors from several war hospitals discussed cases treated with the antibiotic. As Major General William H. Ogilvie, Consultant Surgeon to the British Expeditionary Forces in the Middle East, noted in a report on the conference, there was a tendency among military doctors to overstress the value of antibiotic treatment. They described a positive treatment result as 'marvellous', forgetting that similar results could be achieved by means of traditional and simpler methods. ${ }^{12}$ As the reports presented at the conference suggested,

${ }^{10}$ Attempts to obtain penicillin were made independently in the Soviet Union. The Third Reich and its allies did not produce the drug.

${ }^{11}$ T. Duncan M. Stout, War Surgery and Medicine, Wellington, 1954, p. 14.

${ }^{12}$ Royal Society Archives in London (hereafter RSA), 98 HF 36.8.9, p. 3. 
in the case of minor wounds the superiority of antibiotic treatment to the traditional treatment was negligible, and when it came to the treatment of bone damage, with some exceptions the effects were even 'disappointing'. ${ }^{13}$ On the other hand, in the case of large, infected wounds the effect of penicillin treatment was so encouraging that - as Ogilvie put it - it could be said 'without hesitation that a new standard had been set.' ${ }^{14}$

This very cautious opinion of the British forces' chief surgeon was undoubtedly influenced by the fact that in very few patients in a similar condition underwent antibiotic and traditional treatment, which made it impossible to compare the effects of the two methods. Such an experiment was conducted only by J.S. Jeffrey from the British 48th War Hospital. The patient treated by Jeffrey with penicillin recovered more quickly than a soldier with a similar wound but treated traditionally. Ogilvie hailed this as 'one of the most convincing demonstrations' of the therapeutic values of penicillin. ${ }^{15}$ Generally, however, he complained that the research carried out during the fighting in North Africa 'lacked the spirit of impartial enquiry that would have made its lessons more convincing. ${ }^{16}$

Florey, who during the Tripoli conference discussed the method of producing the antibiotic, admitted that the process was still complicated and that the substance obtained was unstable and hard to titrate. Practically every batch produced had to be individually tested with regard to its efficacy in order for doctors to be able to determine the right doses. ${ }^{17}$ Purified penicillin, which the British army doctors had at their disposal during the Sicilian campaign, was delivered as calcium or sodium salts containing 5,000 Oxford units per 1 gram of powder. ${ }^{18}$ Sodium salts, as non-soluble in water, were used as dusting powder in local treatment. Potassium salts were used to prepare an aqueous solution containing 250 Oxford units per cubic centimetre to be used in intramuscular injections or, even more diluted, in local applications.

Owing to the thermal instability of purified penicillin, its application in medical outposts located near the front line was fraught with difficulties. In any case, the discussion in Tripoli did not suggest that

13 Ibid., p. 4.

14 Ibid., p. 5.

15 Ibid.

16 Ibid.

17 Ibid., p. 3.

${ }^{18}$ The Oxford unit is an international standard defining a penicillin amount and introduced in 1944. One unit equals 0.606 microgram of crystalline sodium salt of penicillin, that is pure antibiotic. 
such a practice brought particularly beneficial effects. On the basis of reports from Sicily, Ogilvie concluded that the effects of penicillin treatment of the wounded in outposts located near the front line and then repeated antibiotic treatment in a general hospital 'were not demonstrably better' that those of treatment administered only after the wounded were brought far away from the front line.${ }^{19}$ However, the conference report ended with a declaration that the British Army's medical services would gladly accept any quantity of penicillin.

Before the British, Canadian and, above all, American pharmaceutical industry could make this wish come true, doctors managed as best as they could. Penicillin was commonly regarded as a panacea which could help in any case. In the United States and United Kingdom many scientists and doctors attempted to obtain penicillin by means of laboratory methods. ${ }^{20}$ The idea of 'home-made penicillin' became popular particularly in America in a period when the drug was unavailable for civilian patients. In November 1943, during a medical conference in Pittsburgh, participants discussed the idea of producing penicillin at home using equipment available in every kitchen. ${ }^{21}$ Although crude penicillin could be used only in local treatment, this made it possible to save the purified form of the drug, which could then be used in general treatment.

Experiments were carried out also by army doctors in the Middle East. Between July 1942 and April the following year Pulvertaft received so little penicillin from Florey's laboratory that it was enough to treat only a dozen or so patients. ${ }^{22}$ At that time standards of antibiotic treatment had not yet been set, so Pulvertaft experimented with dosage and application method. In order to finish treatments which had already been started, from March 1943 he used a crude penicillin broth from the hospital laboratory in Cairo. Not only did he use crude penicillin for compresses and washing of wounds, but he also experimented with penicillin injections. ${ }^{23}$

Florey appreciated the significance of clinical trials conducted by Pulvertaft, but regarded the attempts to produce a crude form of the drug as a waste of effort and resources. ${ }^{24}$ Some people even claimed that the

${ }^{19}$ Ibid., p. 4. This view was challenged by the experiences of Polish doctors in the Italian campaign, as will be discussed later on in the article.

${ }^{20}$ Milton Wainwright, 'The History of the Therapeutic Use of Crude Penicillin', Medical History, 1987, 31, p. 41.

21 'Making Penicillin in Home Suggested: Dr. Vogel Says Physicians can Produce It in Own Family Kitchen at 5c a Dish', New York Times, 11 November 1943, p. 24.

${ }^{22}$ Robert Pulvertaft, 'Local Therapy of War Wounds with Penicillin', The Lancet, 18 September 1943, pp. 342-45.

${ }^{23}$ Ibid., p. 344.

${ }^{24}$ Howard Florey to L. Poole, 11 May 1943, RSA, 98 HF 36.24.40. 
production of crude penicillin was harmful. In early 1944 The Lancet called for penicillin production to be legally regulated, because otherwise 'any yellow liquid' would be sold under that name. ${ }^{25}$ What came to be used as the key argument in the debate was a situation from the Sicilian campaign, when washing wounds with crude penicillin led to even worse infections. The Lancet said explicitly that although Pulvertaft achieved good results, other military laboratories should not follow him.

As a result of constant improvements in industrial production methods and the increasing efficiency of factories, the amount of penicillin at the disposal of the Allies' medical services was growing quickly. A turning point came in mid-1944. After the opening of a new front in Normandy, Allied hospitals in Europe and the Middle East were virtually 'swimming in penicillin' to quote Florey. ${ }^{26}$ The drug came mainly from American supplies.

\section{From Refugees to Doctors}

The analysis of the beginnings of the Polish doctors' efforts to obtain penicillin in field conditions in wartime would be incomplete without a presentation of events which brought together the main protagonists of the story. A key role was played by Odrzywolski, but he would not have been able to achieve any breakthrough in his penicillin research on his own, without the help of two members of his team, Janina Michniewicz and Zygmunt May. Following the upheavals of the first few years of the war and constant regroupings of the Second Polish Corps in the Middle East, all three met in Palestine. They all had the relevant and complementary education. Odrzywolski graduated in medicine from the University of Warsaw in 1930 and two years later began specializing in bacteriology at the University's Department of Hygiene, where he was made assistant professor, a position he held until the outbreak of the war. He was a member of the Polish Society of Social Medicine and from 1938 editor-in-chief of the Lekarz Polski monthly. Michniewicz had a master's degree in pharmacy and May was a chemical engineer.

All three were called 'Orthodox' in the Second Corps jargon, that is refugees from the Soviet Union, where they had found themselves as a result of the Soviet annexation of the eastern part of Poland after

25 'Home-made penicillin', The Lancet, 8 January 1944, p. 57.

${ }^{26}$ Literally: 'The place is now swimming in penicillin, mainly of American origin.' H. Florey to Pulvertaft, 5 July 1944, RSA, 98 HF 36.8.19. 
17 September $1939 .{ }^{27}$ Odrzywolski, after serving briefly as an army doctor in the September campaign, was arrested by the Soviet authorities. He escaped and was caught again, receiving a sentence of eight years in a forced labour camp in Siberia. ${ }^{28} \mathrm{He}$ was released thanks to the amnesty under the Agreement of 30 July 1941 on the establishment of the Polish Army in the USSR, and managed to get to the Army Reserve Centre in Totskoe in southern Russia, near the Kazakhstan border, were Polish units were being formed. He immediately joined their medical service and was evacuated to Iran, ${ }^{29}$ via the Caspian Sea to the port of Pahlavi (today Bandar-e Anzali). This was the route through which over 100,000 Poles got out of Russia. ${ }^{30}$ They included

${ }^{27}$ In addition to the 'Orthodox', there were also 'Lords' and 'Ramseses'. The etymology of this colloquial classification is explained by Jan Kochanowski, a surgeon from the 4th War Hospital: "The "Lords" were those who at the beginning of the war got to France and then England via Romania, Hungary or other route, and only from there were sent to the Middle East; the "Ramseses" were those who through Turkey first arrived in Syria and from there went to Palestine and Egypt, where they waited for further developments. Finally, the "Orthodox" were those who got to Persia via the Caspian Sea and the city of Pahlavi and then were organized in Tehran.' See Jan Kochanowski, 'Wspomnienia z lat wojny 1939-1944: Szpital wojska polskiego nr 4 w Mossulu (Irak)', Archiwum Historii Medycyny, 32, 1969, 1, pp. 217-25 (p. 217). A 'Lord' himself, Kochanowski believed that the different stories of the Second Corps doctors in the first few years of the war were not without influence on their relations. This also applied to pre-war acquaintances. Meeting in a completely new situation in Iraq, they entered into informal alliances determined by the direction from which they had come to the Middle East. According to Kochanowski, 'an Orthodox was automatically in opposition to a Ramses and a Lord, despite past friendship.' Ibid., p. 219.

${ }^{28}$ Witold Marian Odrzywolski - Application for a Certificate of Naturalisation, 11 January 1965, The National Archives in London (hereafter TNA), HO 405-40788, p. 3. In his application Odrzywolski wrote that he had been exiled to Siberia, although he did not give the exact location of the camp. He may have served at least part of his sentence at Ukhtizemlag in the Komi Republic, that is in the European part of the Soviet Union. Doctor Odrzywolski, who despite lacking medications helped his fellow prisoners, saving the lives of hundreds of them, was mentioned by Julian Wołoszczuk, who was in the camp between March 1940 and February 1942. See Julian Wołoszczuk's testimony, Pilecki Institute, 〈http://www.zapisyterroru.pl〉 [accessed 12 December 2019].

${ }^{29}$ The information about the beginnings of his service in the Second Corps included in the application for British citizenship is not precise. At one point we read in it that Odrzywolski joined the medical corps of the Polish Army already in the Totskoe camp and elsewhere - that he served in the Polish forces under British command from August 1942. Presumably, the date refers to the transfer of the Polish unit under British command, which happened only after the evacuation to Iran.

${ }^{30}$ Janusz Wróbel, Uchodźcy polscy ze Zwiazku Sowieckiego 1942-1950, Łódź, 2003, p. 48. According to Kruszyński's earlier estimates, the number was even as high as 115,000. See Michał Kruszyński, 'The State of Health of Poles Evacuated from Russia to Persia in 1942', Antemurale, 20, 1976, pp. 132-205 (p. 192). In early 1943 in Tehran alone there were nearly 19,000 Poles, 17,000 of whom were women and children. See Marek 
Michniewicz and May, who as early as at the beginning of April 1942 volunteered to join the Polish Central Civilian Hospital, which was being formed in Tehran at the time. ${ }^{31}$ She was a deputy of the chief pharmacist, while he was in charge of the hospital's warehouse and chemical laboratory.

Owing to the poor health of the refugees from the Soviet Union, several more Polish civilian hospitals were set up in Iran at the time. ${ }^{32}$ Their personnel was recruited mainly from among the refugees themselves. ${ }^{33}$ After the main wave of evacuations these facilities were no longer needed and after being turned into war hospitals they were moved to the West. They followed the entire Polish forces, which after leaving the Soviet Union became subordinated to the British Persian and Iraq Command (PAIFORCE or PAIC) and reorganized to make them correspond to the structure of the United Kingdom's army and able to perform tasks set by its command. Their relocation to the West began in May 1942 and the route took them through Iraq, Syria, Palestine and Egypt to Italy, sometimes even farther, to England.

Two of the civilian medical units set up in Iran at the time played a role in the events described here, because this was where, after their transformation into war hospitals, all later members of Odrzywolski's team worked. And so after leaving the Central Civilian Hospital and undergoing short training at the Women's Auxiliary Centre, in April 1943, Michniewicz began serving at the 4 th War Hospital. ${ }^{34}$ It began as the Polish Red Cross hospital, which in late December 1942 was moved from Tehran to Mosul and reorganized, becoming a war hospital. Michniewicz became a technician at the hospital's bacteriological laboratory. It is

Ney-Krwawicz, “"Polak w Iranie” o młodych i najmłodszych uchodźcach polskich z ZSRR w Iranie w latach 1942-1944', DN, 46, 2014, 1, pp. 85-110 (p. 91).

${ }^{31}$ Kruszyński, 'The State of Health', p. 140.

32 The health status of the Polish population, both civilian and military, in Iran is discussed for example by Stefan Wojtkowiak, Służba zdrowia $w$ armiach zachodnich aliantów i w Polskich Siłach Zbrojnych na Zachodzie, Łódź, 1972; Wróbel, Uchodźcy polscy, pp. 72-73; Zbigniew Moszumański and Zbigniew Palski, Wojsko Polskie w Iraku: Historia i wspótczesność, Warsaw, 2003, pp. 79-82; Brzeziński, Służba zdrowia, pp. 129-30; Katarzyna Śliwak, 'Delegatura Ministerstwa Pracy i Opieki Społecznej w Teheranie w latach II wojny Światowej - charakterystyka działań edukacyjnych dla polskich uchodźców', Ogrody Nauk i Sztuk, 5, 2015, pp. 261-68 (p. 265).

33 In May 1943 in the Middle East there were 526 doctors of various specialities, including 20 women. Brzeziński, Służba zdrowia, p. 132.

${ }^{34}$ Order no. 44, 5 April 1943, Archiwum Instytutu Sikorskiego i Muzeum im. Gen. W. Sikorskiego w Londynie - Archives of the Sikorski Institute and Sikorski Museum in London (hereafter AIS), Dowództwo Armii Polskiej na Wschodzie (Polish Army Command in the East), no. R. 10, Daily Orders 1943, p. 3. 
almost certain that May began his service at the hospital together with her; they may have already become a couple by then, although they got married only when they got to Egypt. In July 1943 the hospital set out for Palestine, first reaching Kefar Bilu near Rehovot, 30 kilometres south of Tel Aviv, where it remained without being deployed for a week, and then arriving in Nuseirat near Gaza, formally on the Egyptian territory. ${ }^{35}$

In November 1943, after a four-month stay in Nuseirat, the unit was again moved to Kefar Bilu, where in the meantime the 3rd War Hospital, with which Odrzywolski had arrived in Palestine, had opened. Formerly the 1st Civilian Hospital in Pahlavi, in late January 1943, after being transformed into a military unit, it was transferred to Quizil-Ribat north of Bagdad, the headquarters of the Second Corps command. It was there that in mid-February a Mobile Bacteriological Laboratory was set up..$^{36}$ It was an independent unit but attached to the 3rd Hospital for organizational and economic reasons. It was founded and headed by Lieutenant-Colonel Władysław Dybowski, sent from Palestine to monitor the epidemiological condition of the Polish troops. ${ }^{37}$ Odrzywolski joined the laboratory in late summer 1943, when it was stationed in Kirkuk. ${ }^{38}$ We do not know the de-

${ }^{35}$ Eugeniusz Mierczyński, Wojenne wspomnienia chirurga, Warsaw, 1983, p. 139. The Poles took over an area previously occupied by New Zealanders, right by the sea. Formally, the hospital was on Egyptian soil, but it was subordinated to the Rehevot-based Polish command in Palestine. After opening, the hospital admitted the first patients on 6 August 1943.

${ }^{36}$ The laboratory had a truck, which helped it move around, but - according to Dybowski - by no means justified the description 'mobile' used with reference to it. In Dybowski's view the laboratory was more portable than mobile. Medical training data from the Polish Mobile Bacteriological Laboratory, 15 May 1945, Archiwum Polskiej Akademii Nauk (Archives of the Polish Academy of Sciences in Warsaw) (hereafter APAN), Władysław Dybowski (1892-1969), no. III-196, file 51, leaf 7.

${ }^{37}$ The laboratory tasks included carrying out diagnostic tests and collecting information about the Polish soldiers' health. Initially, Dybowski had a personnel of only two. This is indicated in the order of movement from Quizil-Ribat of 29 July. We do not know if it covered Zofia Chowaniec-Sieniawska, an assistant who two months earlier had come as a volunteer from Palestine after undergoing training at the Women's Auxiliary Centre. See Troop Movement Order, 29 July 1943, APAN, Władysław Dybowski (1892-1969), no. III-196, file 51, n.p.; Ośrodek Zapasowy P.S.K., 27 October 1943, APAN, Władysław Dybowski (1892-1969), no. III-196, file 51, leaf 26.

${ }^{38}$ When on 30 July Dybowski moved with the lab from Quizil-Ribat to Kirkuk, he was accompanied only by two unnamed privates. But when on 27 September the lab set out from Kirkuk to Palestine, the team included - in addition to Dybowski and most likely the same privates, Ignacy Tarasiewicz and Sylwester Zarzycki - Odrzywolski and Zofia Chowaniec-Sieniawska. See Troop Movement Order, 29 July 1943, APAN, Władysław Dybowski (1892-1969), no. III-196, file 51, n.p.; Certificate, n.d., APAN, Władysław Dybowski (1892-1969), no. III-196, file 51, leaf 23. 
tails of his service after the evacuation to Iran. We only know that in late 1942, while he was still a sergeant assigned to the 3rd War Hospital organized at the time, he completed a two-week course in diagnosing tropical diseases in the mobile laboratory of the British 10th Army. ${ }^{39}$ The main core of the hospital moved to Palestine in September 1943, with Dybowski's mobile laboratory team, which included Odrzywolski, following in early October. ${ }^{40}$

During the two hospitals' joint stopover in Kefar Bilu, they were reorganized with regard to their future tasks. The 3rd War Hospital was ordered to move to Italy, taking with it the Mobile Bacteriological Laboratory. It was to support the Polish medical services during the Italian campaign. Odrzywolski was transferred to the bacteriological laboratory of the 4th War Hospital, which was to remain in the Middle East and receive more seriously wounded soldiers sent there from the Italian front. In the laboratory, headed by Major Strzelecki, he met his future collaborators, Michniewicz and May. In February 1944, when Strzelecki joined the 3rd Hospital setting off for Italy, Odrzywolski took over the entire responsibility for the functioning of the laboratory. ${ }^{41}$

At the same time the 4th Hospital was moved to Al Qassasin, 35 kilometres east of Ismailia in Egypt. After settling in the new location, the laboratory resumed normal diagnostic work. It was there that in April 1944 Odrzywolski began working on obtaining penicillin. He had at his disposal the so-called Fleming strains, that is strains derived from those isolated by the discoverer of the therapeutic properties of penicillin. As has already been said, the Poles received them during their stay in Palestine, that is between November 1943 and February 1944, at least two months earlier than suggested by the BMJ. Moreover, the strains used in those experiments did not come straight from Florey, but from two Jewish researchers, the microbiologist Baruch Levin from the Hebrew University in Jerusalem, and the chemist Leon Haskelberg from the Daniel Sieff Research Institute in Rehovot. $^{42}$

39 Order no. 216, 29 January 1943, AIS, Dowództwo Armii Polskiej na Wschodzie (Polish Army Command in the East), no. R. 10, Daily Orders 1943, p. 3. The daily order mentions, 'for the record', that the training course took place between 30 November and 13 December 1942, when the hospital was being organized.

${ }^{40}$ The laboratory was assigned to the so-called malarial camp, a branch of the $3 \mathrm{rd}$ War Hospital. Ośrodek Zapasowy P.S.K., 27 October 1943, APAN, Władysław Dybowski (1892-1969), no. III-196, file 51, leaf 26.

${ }^{41}$ Mierczyński, Wojenne wspomnienia, p. 140.

${ }^{42}$ Witold Odrzywolski, 'Przygotowywanie penicyliny i zastosowanie lecznicze penicyliny surowej’, in Pamiętnik Zjazdu Polskich Lekarzy Wojskowych w Bolonii, ed. Tadeusz Sokołowski, Bari, 1946, pp. 103-14 (p. 103). 


\section{The Palestinian Connection}

The transfer of the Penicillium notatum strains was undoubtedly facilitated by the fact that the 3rd and 4th War Hospitals were stationed near Rehovot, the location of the famous Daniel Sieff Research Institute, founded by Chaim Weizman in $1934 .{ }^{43}$ The Hebrew University was not far away either. We do not know how contacts between the Polish doctors and local scientists were established. Some role may have been played by affection for Poland, ${ }^{44}$ where both scholars mentioned by Odrzywolski were born: Leon Haskelberg was born in Warsaw, ${ }^{45}$ and Baruch Levin in Vilna (Vilnius). ${ }^{46}$ Moreover, Levin and Haskelberg may have been guided by a belief that achievements of medical sciences should be disseminated regardless of national or political differences. ${ }^{47}$ Or perhaps in helping the Polish military doctors the Jewish scientists wanted to support them in the fight against a common enemy - Nazi Germany.

Irrespective of the motivation behind the sharing of the Penicillium notatum strains, the crucial question is how the strains had found their way to Palestine. As has already been said, Leon Haskelberg was a chemist

${ }^{43}$ It was not until 1949 that its name was changed to the Weizmann Institute of Science.

${ }^{44}$ Accounts and memoirs of members of the Second Corps' medical personnel stress great sympathy shown to them in Palestine by the local Jews, mostly recent immigrants from Poland. Families were united and old friends separated by the war met again. Siostra J. May, AIS, col. 291, vol. 23, leaf 99 and 112.

${ }^{45}$ Haskelberg completed his secondary education in Warsaw and left for Belgium to study in Liège. After his studies he emigrated to Palestine, where he continued his education as one of the first students of the Hebrew University in Jerusalem. In 1934 he began working at the institute in Rehovot. 'Dr. Haskelberg, Israeli Scientist, Dies; Collaborator of Weizmann', JTA. Daily News Bulletin, 20, 19 January 1953, 12, p. 6.

${ }^{46}$ Baruch Samuel Levin was a son of a leading Zionist activist, Shmaryahu Levin. His father was elected to the First State Duma in 1906, but after its dissolution had to leave Russia with his family. The Levins settled in Berlin, where Baruch completed his secondary education. His most vivid memory from that period was mathematics classes with Albert Einstein. In 1923 he emigrated to Palestine, where he took up agriculture, specifically chicken breeding in Nahalat Yitzhak, a settlement not far from Tel Aviv. As he would later say, 'this unconsciously sparked' his latent interest in the subject of microbiology, for he was struck by probably all tropical diseases it was possible to catch there at the time. 'I wanted to find out how many diseases I still had to go,' he joked in an interview he gave many years later. M. Kaskim, 'The Biggest Medicine Man', Jerusalem Post, 10 April 1959, p. II.

${ }^{47}$ Such values were cherished by Pulvertaft as well. When his laboratory was visited by Turkish doctors, he gave them strains of Penicillium notatum, thus violating the order of the military authorities, which considered penicillin to be material of strategic significance. Wyatt, 'Robert Pulvertaft's Use of Crude Penicillin', p. 324. 
working at the Sieff Institute and a collaborator of no less a figure than Chaim Weizman. However, he dealt mainly with organic chemistry (for example, developing a method for producing nylon from castor oil), and we do not know how he laid his hands on an active strain of penicillin, which he gave to the Poles. In any case, we cannot be certain whether he knew anything about growing the mould at all.

There are no such doubts in the case of Levin, who was a pioneer of penicillin research in Palestine. In 1937 Baruch, or Boris Samuel Levin, with his microbiology PhD from the Sorbonne began working at the Department of Hygiene and Bacteriology, Hebrew University. ${ }^{48} \mathrm{He}$ focused mainly on the question of continued cultivation of microorganisms. ${ }^{49} \mathrm{He}$ continued his research in the field in the Rafa pharmaceutical company, which he founded in Jerusalem in 1943. At the beginning of the following year he applied for patents in the United States and the United Kingdom for his method and the equipment necessary for its application. ${ }^{50}$ The process developed by Levin considerably sped up the transformation of microorganisms. Experiments with Bacillus anthracis demonstrated that within one year it was possible to obtain so many generations of the bacterium that would take five hundred years for the traditional agar plate method to achieve the same result. ${ }^{51}$

${ }^{48}$ He published his doctorate in 1936. See Baruch S. Levin, Action des lipoïdes sur les phénomènes de la lyse, Paris, 1936.

${ }^{49} \mathrm{He}$ published a report on the research already in early 1939. See Baruch S. Levin and Leo Olitzki, 'Effect on Bacteria of Continued Cultivation in Lecithin Broth', Nature, 9 April 1939, 3623, pp. 604-05.

${ }^{50}$ The heart of the device was a small loop made of platinum wire on which a lamella was formed from one or two drops of the medium. After the medium was inoculated with the selected organisms (bacteria, unicellular protozoa like amoebas and spirochaetes or unicellular plants, like candida and algae), drops of the medium fell straight onto the loop, mixing with the fluid in the lamella. Excessive fluid flowed away to the bottom of the receptacle, rinsing out metabolic products and most of the microbial accretions. Consequently, the composition of the medium on which the growth took place remained practically unchanged. In addition, the dribbling excessive medium washed out most of the microorganisms, thanks to which a new generation grew in the lamella in the new cycle. Thanks to a modification of the composition of the medium as well as other physical-chemical parameters in which the process took place, the microorganisms in question could constantly evolve. See Baruch Levin, A method of and Apparatus for Cultivating Micro-Organisms, British patent no. 588,374, submitted in Palestine on 17 July 1944, granted on 21 May 1947. Levin also was granted a patent in the United States: Baruch Levin, Apparatus and Process for the cultivation of microorganisms, American patent no. 2,439,572, submitted on 15 March 1944, granted on 13 April 1948.

${ }^{51}$ Levin achieved similar results with Vibrio cholerce (cholera), Pasteurella (fowl cholera) and Shigella varieties (dysentery). Thus the new method was applicable especially in the production of vaccines. 
The apparatus not only sped up the production of modified microorganisms to be grown further, but also made it possible to recover the products of their metabolism. It could thus be used, for example, to produce penicillin, although we do not know whether Levin experimented in this field. If he had not, he began to do so, when in mid-March 1944 Florey arrived in his laboratory. He was returning from a four-week medical mission to Moscow the objective of which was to introduce the Western Allies to the Russians' achievements in military medicine and the other way round - to share the Western experiences with the Russians. In addition to Florey and Arthur Gordon Sanders, who represented the United Kingdom on account of their experience in the production and use of penicillin, the mission included two Americans, the biochemist A. Baird Hastings and the surgeon Michael B. Shimkin. The latter spoke fluent Russian because of his origin and also served as an interpreter. ${ }^{52}$

When they went to Moscow the British doctors took with them Penicillium notatum strains as well as samples of the ready-made drug. On their way back they spent a few days in Palestine, although they did not plan to do so initially. Florey and Sanders flew from Moscow via Baku and Tehran to Cairo. Before leaving for Casablanca and then to England, thus encircling Nazi-occupied Europe, they planned a short holiday in southern Egypt. In the end they cut their holiday short and travelled East again, visiting the American University in Beirut, Hebrew University in Jerusalem and the Sieff Institute in Rehovot. In Jerusalem Florey gave two lectures on penicillin, separately for the Arabs and the Jews. ${ }^{53}$

${ }^{52}$ A. Baird Hastings and Michael B. Shimkin, 'Medical Research Mission to the Soviet Union', Science, 103, 17 May 1946, 2681, p. 605.

${ }^{53}$ A row erupted in connection with the event. Announcing Florey's visit, the Palestine Post initially said that Florey would deliver a lecture for doctors under the auspices of the Palestine Arab Medical Association (PAMA) as well as a public lecture in the YMCA auditorium ('Penicillin Pioneer to Lecture in Jerusalem', Palestine Post, 8 March 1944, p. 3). Believing that the lecture would not be open to the Jewish medical community, doctor A. Rosenbaum accused the British mandate authorities of mixing politics and science. In a letter to the newspaper he asked rhetorically how an Arab penicillin treatment differed from a Jewish, British or South African treatment and accused the authorities of using penicillin as a political tool. He believed that the authorities should organize one lecture at a neutral venue for all doctors and scientists in Palestine, a 'large and representative assembly of medical men and natural scientists, Arabs, Jews, British, Poles, Czechs and so on, both civil and military' ('Penicillin Politics', Palestine Post, 10 March 1944, p. 4). J.S. Morrison from the British Council office in Jerusalem, which organized Florey's visit to Palestine, explained that a separate lecture for Jewish doctors was planned under the auspices of the Hadassah Medical Centre, that is a Jewish institution associated with the Hebrew University. Morrison argued that this was dictated by technical considerations; the lecture was 
The two Britons began to write a report on their mission already when they were on their way back. According to Florey, one of its most important parts was the one devoted to Levin's work in Jerusalem. He was completely surprised by what he saw in his laboratory. Edward Mellanby from the Medical Research Council, to whom Florey reported on his mission, agreed with him and wanted to pass the information about Levin's method as quickly as possible to the General Penicillin Committee. ${ }^{54} \mathrm{He}$ thought that there was "more than a chance that it may supersede their attempts to grow this organism, including the deep culture method.' 55

After Florey left Palestine, Levin began to publicize his research on a much larger scale. Either he was encouraged by the interest shown by the famous scientist or under the influence of this interest he decided to emphasize his rights to a possible scientific breakthrough. ${ }^{56} \mathrm{He}$ presented his method for continued cultivation of microorganisms for the first time in late April at the annual congress of the Palestine Microbiological Society (today, the Israel Society for Microbiology), noting that he had worked on

to include a film screening and there was no sufficiently big room in Jerusalem with the right equipment ('No Penicillin Politics', Palestine Post, 12 March 1944, p. 4). Particularly disappointed with such an organization of Florey's visit to Palestine was the medical community in Tel Aviv, where no separate lecture was planned. Among the 2000 doctors practising in Palestine, as many as 900, mostly Jews, were living in that city. They believed they had a right to expect that like in the case of PAMA, the mandate authorities would agree for Florey to deliver a lecture for members of the PJMA (Palestine Jewish Medical Association), which did not happen, however (see 'Points from Readers' Letters', Palestine Post, 14 March 1944, p. 4).

${ }^{54}$ Edward Mellanby to H. Florey, 14 April 1944, RSA, 98 HF 47.1.65.

${ }^{55}$ Ibid.

${ }^{56}$ Florey assured Levin that in England his work attracted a lot of interest (see H. Florey to Pulvertaft, 26 May 1944, RSA, 98 HF 36.24.106). There is no evidence that the method was used - given the interest in it so openly declared by Florey - in the British pharmaceutical industry. But it was in Palestine. In April 1945 the Hebrew University announced that Levin would start producing penicillin in the University's laboratory ('Hebrew University Will Produce Penicillin', JTA. Daily News Bulletin, 12, 13 August 1945, 185, p. 2). By August as many as ten million Oxford units of crude penicillin were produced every month, although Levin claimed that he could easily increase the production level fourfold, if he had more room ('Over 10,000,000 Units of Penicillin Produced Monthly by Jewish Scientist in Palestine', JTA Daily News Bulletin, 12, 28 August 1945, 197, p. 4). He explained that no attempts were made to obtain the antibiotic in its purified form, as the cost of such an operation would have been too high. Significantly, he would later say that 'the mandate authorities refused to allow him to invade the budding field of antibiotics.' The decision to build a full scale penicillin factory was announced only after the establishment of the State of Israel, in April 1949. Baruch Levin became a scientific and technical advisor in the venture, the value of which was estimated at two million dollars. Kaskim, 'The Biggest Medicine Man', p. II; 'Penicillin Plant Proposed: Steps Taken to Make Wonder Drugs Here', Palestine Post, 18 April 1949, p. 3. 
it at the Hebrew University for over a year. ${ }^{57}$ The press all over the world reported that a way had been invented in Jerusalem of reducing the time needed to produce crude penicillin from ten days to merely one hour..$^{58}$

\section{The First Polish Penicillin}

While we know the origin of the strains used by Odrzywolski in his experiments, we do not know what prompted him to undertake the research and where he acquired the necessary knowledge. It is almost certain that he had heard about Pulvertaft's work and may have even met him in Egypt. ${ }^{59}$ Odrzywolski may have received the basic information about the cultivation of Penicillium with its strains, but this does not explain why he waited nearly two months to begin his experiments. Presumably he was inspired by Florey's visit to the Middle East. Although the Polish hospital had left Palestine several weeks earlier and it is rather unlikely that Odrzywolski managed to get from Al Qassasin in Egypt to Jerusalem to attend one of his lectures. But he may have heard Florey's lecture on penicillin delivered on the Palestine radio on $16 \mathrm{March}$. The programme was broadcast by the Broadcasting Service from Ramallah, well heard across the Middle East and Egypt. ${ }^{60} \mathrm{~A}$ few week later Levin discussed his method of quick penicillin production on the same radio station. ${ }^{61}$

We know nothing about Odrzywolski's feelings from that period, but when recalling the beginnings of the penicillin research, Michniewicz explains that at least she was 'concerned' about the fact that nothing was being done with the strains brought from Palestine. The laboratory re-

57 'Method for Speeding Penicillin Production Developed at Hebrew University', JTA. Daily News Bulletin, 11, 28 April 1944, 97, p. 2.

58 'Speed Penicillin Output', New York Herald Tribune, 27 April 1944, p. 17.

${ }^{59}$ Pulvertaft certainly met with Odrzywolski's former boss Dybowski during his short stay in Egypt (see Medical training data from the Polish Mobile Bacteriological Laboratory, 15 May 1945, APAN, Władysław Dybowski (1892-1969), on. III-196, file 51, leaf 9). Among other encounters with eminent doctors in Egypt Dybowski mentioned van Royen (the full name has not been identified) and among those associated with the PAIC - Albert Sachs, who was involved in combating the epidemic of typhus fever brought from Soviet camps by Polish refugees. See Albert Sachs, 'Typhus Fever in Iran and Iraq, 1942-43: A Report on 2,859 Cases', Journal of the Royal Army Medical Corps, 86, 1946, 1, p. 5 .

${ }^{60}$ The station broadcast mainly in English, although news bulletins were also broadcast in Hebrew, Arabic, Polish, French, Turkish and German. Palestine Post, 16 March 1944, p. 2.

${ }^{61}$ Palestine Post, 24 April 1944, p. 2. 
quested from the British the material necessary to start the culture, including the medium. The Poles got everything 'without a single item being crossed off the list,' as Michniewicz stressed in her memoirs ${ }^{62}$ The experiment began in a small room in which after the windows had been covered and blocks of ice delivered it became possible to lower the temperature to 22-24 degrees Celsius, conditions in which mould inoculated onto the medium in several ordinary whisky or gin bottles began to grow normally. It was only then that the culture was transferred to the laboratory, where an 'icestat' was used to maintain the right temperature. ${ }^{63}$ The moment of the transfer of the culture made a huge impression on the hospital's staff: 'We walked together, I was carrying a tray on which our penicillin was growing in ordinary angular bottles. Doctors and nurses ran out of their wards and admiringly murmured 'they're carrying penicillin, they've made penicillin'. Yes, we grew penicillin, working in conditions similar to those in which Ms Skłodowska worked, slightly different though, because she worked in winter, and we in tropical heat. ${ }^{64}$

The work was not regarded as particularly confidential. Michniewicz recalled that on hearing about the Polish experiments, 'the English from the neighbouring hospital laughed; they had tried several times and failed. ${ }^{65}$ It was only when the news about the growth of the culture spread, that British officers began coming to the Polish hospital: 'they walked around the laboratory, wearing their hats, everyone had a cane under his arm and would give a salute by raising the cane to the peak. ${ }^{66}$ Odrzywolski was often invited to visit British war hospitals (for example in Suez) to talk about how he had managed to repeat Pulvertaft's feat and obtain active penicillin.

After the war, when addressing the Congress of Polish Military Doctors in Bologna in late 1945, he said that the objective of his experiments was to obtain the antibiotic in its crude form, which, although not very durable and containing quite a lot of impurities, was very well suited to local treatment. He added, however, that from the very beginning he toyed with the idea of developing the production to a level that would make it possible to obtain purified penicillin, suitable for general

62 Siostra J. May, AIS, col. 291, vol. 23, leaf 118.

${ }^{63}$ Ibid., leaf 119 . Writing about the events years later and consistently referring to her future husband as 'engineer', Janina Michniewicz recalled this in the following manner: 'the engineer came up with the idea of turning a thermostat into an icestat, astonishing the world; some alterations done with his own hands and we moved from this tiny room to the icestat in the laboratory.'

${ }^{64}$ Ibid.

${ }^{65}$ Ibid., leaf 118.

${ }^{66}$ Ibid., leaf 119. 
treatment. ${ }^{67}$ His paper clearly suggested that the entire venture was not only about the welfare of the patients suffering there at the time, but also about gaining experience in the production of the new drug, experience which could prove useful after the war.

In mid-1944 the British command ordered the 4th Hospital to be transferred to England. The Polish military authorities took this opportunity to reorganize the unit, excluding from it the most experienced personnel, which joined the 8th War Hospital in El-Qantara on the Suez Canal. ${ }^{68}$ With its 1,200 beds the hospital admitted mainly wounded Second Corps soldiers from the Italian front. Odrzywolski and his closest associates remained in Egypt. After moving to El-Qantara, he organized the production of penicillin anew.

As it turned out, as a result of the interruption in the work of the laboratory the strains became degenerated and contaminated, which required a selection of the material. This delayed the launch of the production of the drug, but at the same time helped the Poles gain experience in modifying the properties of the strains. Working with the Czapek-Dox medium, Odrzywolski replaced glucose with brown sugar and iron salts with zinc, copper and manganese compounds, obtaining strains which behaved differently from the original ones, both when it came to efficacy and production of thylakoids. Secondary strains obtained as a result (called AD, WO and WO2) were two to three times more effective in suppressing the growth of Staphylococcus aureus than Fleming's original Penicillium notatum. Although they were less effective than the strains used in the industrial production in America, with which Odrzywolski experimented shortly before the Bologna conference, the effectiveness of the American strain was not 'markedly' higher. ${ }^{69}$

At the El-Qantara laboratory the Penicillium was cultured by means of the surface method in whisky or gin bottles. The bottles were laid flat, with the laboratory staff trying to maintain the fluid depth at 2 to 3 centimetres,

${ }^{67}$ Odrzywolski, ‘Przygotowywanie penicyliny', p. 103.

${ }^{68}$ The hospital remained there until 19 June 1944, when it sailed to the United Kingdom. Anna Bobińska, Pomocnicza Wojskowa Służba Kobiet 2 Korpusu 1941-1945, Warsaw, 1999, p. 172.

${ }^{69}$ In the case of Fleming's strain, with which Odrzywolski began his research, the ability to suppress the growth of Staphylococcus aureus occurred with a dilution of $1 / 24$ to $1 / 32$, while in the case of secondary strains the effect was achieved with a dilution of up to $1 / 80$, and the upper layer of the culture (the so-called dew) - up to $1 / 400$, which corresponded to 8 Oxford units in one cubic centimetre of the broth. Odrzywolski noted that the Penicillium received in 1945 from the United States had a much shorter time of maturation and sporulation (that is creation of spores), which considerably reduced production time. Odrzywolski, 'Przygotowywanie penicyliny', p. 104. 
because in such conditions they were able to obtain the highest concentration of penicillin in the broth. The 'icestat' could accommodate seventy bottles, which made it possible to culture about 17 litres of the medium at a time. From this Odrzywolski obtained about 14 litres of crude penicillin of low efficacy and up to 2 litres of the so-called dew with a titre of $1 / 400$ to $1 / 500$. In total, one culture gave up to 50,000 Oxford units, that is only half a standard phial of purified penicillin produced on an industrial scale. When presenting these figures at the Bologna conference Odrzywolski admitted that these were small quantities and any attempts to obtaine a purified form of the antibiotic in these conditions would have been "pointless to say the least'. ${ }^{70}$

As part of their experiments the Polish researchers also thickened crude penicillin according to a method developed by May. The method 'not used in the industry or in Oxford laboratories,' according to Odrzywolski, consisted in slowly freezing the broth. ${ }^{71}$ As a result, water would precipitate in the form of ice and the remaining liquid would become gradually thicker. This increased the penicillin titre several times in the solution. After extraction with ethyl acetate (used because methyl acetate was not available), the Poles would obtain a solution with a relatively high concentration of penicillin and free from the remains of the medium.

The crude penicillin obtained at El-Qantara was used in regular hospital treatment. A filtrate obtained from one culture was enough for several local treatments. It was used mainly in the treatment of skin diseases caused by staphylococcal and streptococcal infections. Compresses and poultices were saturated with the liquid and were changed several times a day. Crude penicillin was also used to wash out abscess cavities in abscess removal procedures. ${ }^{72}$ As Eugeniusz Mierczyński, one of the surgeons working at El-Qantara, recalled later, the penicillin produced by Odrzywolski, 'although not purified and not in the form of powder but liquid', was used to effectively treat problematic wounds. ${ }^{73}$

Doctors at the hospital were also able to successfully treat forty-five cases of conjunctivitis by instilling drops of crude penicillin with a large titre - that is dew from the surface of the culture - into the patients' eyes. They were also successful in treating four cases of chronic maxillary sinusitis and thirty cases of dental problems cured with crude penicillin. The broth was also used successfully in the treatment

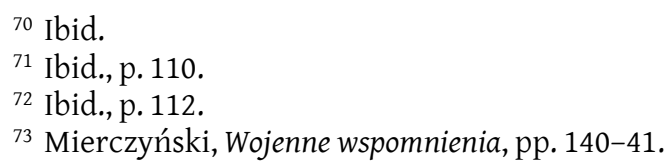


of gynaecological conditions. In the case of persistent erosions the doctors used tampons saturated with it. There were also two successful treatments of gonorrhoeal vaginitis. ${ }^{74}$

\section{The War Will End One Day}

The Polish government in London was aware of the breakthrough in medicine caused by penicillin, so it sought to prepare personnel capable of launching its production in post-war Poland. Initially, in October 1944, the Ministry of National Defence asked the General Penicillin Committee for help in training Second Lieutenant Henryk Kubikowski in antibiotic production. ${ }^{75}$ The plan was for him to be detached for half a year to work in a pharmaceutical facility, where he would be able to get to know the process in practice. The Committee refused, saying that Kubikowski did not have sufficient qualifications to take full advantage of such training. ${ }^{76}$ The Committee suggested that another, better prepared candidate be found and that the best place for his training would be the Royal Navy Medical School in Clevedon. The penicillin production facility there was the only one controlled by the British Ministry of Defence. ${ }^{77}$ As other countries approached the British authorities with similar requests, the Committee, in collaboration with producers, came up with general rules for giving access to production facilities in such cases, because - to quote J.E. Whitehall from Kemball Bishop \& Co. - 'it is unthinkable that we should deny to Russia, France, or any other country such help as we can give in the production of penicillin. ${ }^{78}$

${ }^{74}$ Odrzywolski, 'Przygotowywanie penicyliny', p. 113.

${ }^{75}$ F. Hartley to W.A. Sexton, 23 October 1944, Wellcome Library Archives in London (hereafter WLA), WF-TRC-02-348.

${ }^{76}$ We know little about Kubikowski, so it is hard to say whether the decision was right. He was a pharmacist and must have had some knowledge of penicillin production, if he spoke about the subject (albeit after the war) during a meeting of the Pharmaceutical Society of the Polish Armed Forces in Aberfeldy, Scotland. Dziennik Polski i Dziennik Żołnierza, 21 March 1946, p. 4.

${ }^{77}$ It was also the first facility in the world where mass production of the antibiotic was launched. Roy Girling and Geoff Hale, 'Number Five Elton Road', in Clevedon: Places and Faces, ed. Roy Campbell, Leicester, 2010, p. 63.

${ }^{78}$ J.E. Whitehall to F. Hartley, 14 November 1944, WLA, WF-TRC-02-348. Neither representatives of the industry nor members of the Committee were enthusiastic about the idea of letting representatives of Allied but foreign states in on industrial secrets. During a discussion about the rules of making this knowledge available to those foreigners various ideas were bandied about; they included the idea of giving only affirmative or negative answers to specific questions like 'Are you using corn steep liquor on the medium?'. 
After Kubikowski was rejected as a candidate, the Polish side proposed Odrzywolski, though not to Clevedon but to Oxford. In December 1944 efforts began to have him admitted to Florey's laboratory at the Sir William Dunn School of Pathology. Captain Antoni Fiumel, MD, from the Polish Ministry of National Defence turned with this matter, through Geoffrey R. Edwards, Secretary of the Royal Society of Medicine, to Lady Florey, that is Howard Florey's wife Mary. Informing her of the penicillin research conducted by Odrzywolski at the war hospital in the Middle East, Edwards assured her that after two weeks spent 'in the wonderful circumstances' of Oxford the Polish doctor 'would certainly return to duty with his knowledge very much enlarged.' He also revealed the Poles' true intentions. speaking of multifaceted assistance given by his Society to doctors from all allied countries, Edwards added that the Poles have a very particular need for equipping themselves in every way as well as possible in order that when they return to Poland they may do a good job of work for suffering people. ${ }^{79}$ We could, therefore, say that the Polish authorities' overriding objective was not just to raise the efficiency of the laboratory at the 8th War Hospital, no matter how important this was for the welfare of its patients, but to gain experience needed for any future plans to launch antibiotic production in post-war Poland.

Lady Florey did not fail to stress that the laboratory did not in principle run preparatory courses in penicillin production, but that it would make an exception for a representative of the Polish medical services. ${ }^{80}$ Edwards assured her that the Polish doctor was 'an excellent person', like other Poles, who in his view were "charming and enthusiastic. ${ }^{81}$ Odrzywolski probably arrived in London on 13 December 1944, but it was possible to arrange his visit to the laboratory only after the New Year. The laboratory could not accept anybody until the end of the year and, in addition, Howard Florey had not yet returned from his journey. His wife promised, however, that in the second week of January one-day training in research methods followed in the laboratory would be conducted by Norman Heatley. Since he was not able to 'give individual attention to any member of the medical profession who needs it,' Lady Florey recommended that other members of the Polish medical corps, not just Odrzywolski, take part in this fast-track training course. ${ }^{82}$

\footnotetext{
${ }^{79}$ Geoffrey R. Edwards to Mary Florey, 8 December 1944, RSA, 98 HF 306.26.1.

${ }^{80}$ M. Florey to Edwards, 12 December 1944, RSA, 98 HF 306.26.2.

${ }^{81}$ Edwards to M. Florey, 21 December 1944, RSA, 98 HF 306.26.5.

${ }^{82}$ M. Florey to Antoni Fiumel, 5 January 1945, RSA, 98 HF 306.26.7.
} 
Yet in the end Odrzywolski visited the laboratory on his own. On Tuesday, 9 January, he arrived there forty-five minutes early, which the surprised Heatley did not fail to note in his diary. The visit did not last long and did not make a good impression on the Englishman: 'he [Odrzywolski] seemed to want to know very little or see very little, and I was glad to get rid of him after an hour and a half. ${ }^{83}$ We do not know whether this 'short course on bacteriology', as Odrzywolski would later call his visit to England, consisted of more meetings than just the one with Heatley. ${ }^{84}$ In an official letter of thanks sent to Lady Florey from the Polish Ministry of Defence, Captain Fiumel diplomatically stressed the hospitality of the laboratory, especially of Heatley, who turned out to be 'so very helpful. ${ }^{85}$ Fiumel conveyed Odrzywolski's gratitude for giving him an opportunity to get to know the penicillin research conducted at the laboratory.

Odrzywolski returned to the Middle East, where he continued to work on penicillin for some time. He shared his knowledge and experience with others. In December 1945, in addition to the lecture in Bologna, he delivered a lecture for medical students at l'Université Saint-Joseph in Beirut, discussing various methods of obtaining penicillin, both in laboratory and in factory conditions. ${ }^{86}$ During the lecture he also discussed Polish doctors' experiences with using penicillin during the Italian campaign. The medical services of the Second Corps received some penicillin at the time, with Dybowski becoming responsible for implementing it in the treatment ${ }^{87}$

Like their British colleagues during the Italian campaign, the Polish doctors, too, collected detailed statistical data and compiled reports on penicillin treatment. Their most important observation concerned the link between treatment efficacy and time when penicillin was applied. In other words, the closer to the front line the application, the bigger the chances for a wounded soldier to recover completely. This concerned primarily gas gangrene (phlegmone emphysematosa). Without treatment the mortality rate was as high as 80 per cent; it fell to 65 per cent thanks to treatment with the Anti Gas Gangrene Serum (AGGS). When treating gangrene with penicillin, the British doctors managed to lower mortality to

${ }^{83}$ Norman G. Heatley, Personal Diary. December 1944-August 1945, Jan. 9th Tuesday, WLA, PP-NHE-F-1-23, n.p.

${ }^{84}$ Witold Marian Odrzywolski - Application, TNA, HO 405-40788.

${ }^{85}$ Fiumel to M. Florey, 16 January 1945, RSA, 98 HF 306.26.8.

${ }^{86}$ An extensive summary of the lecture was made by R. Jakubski, most likely one of the participants. Informacje na temat penicyliny - zestawił R. Jakubski, PISK, Zespół Instytutu Polskiego w Bejrucie, no. 141.

${ }^{87}$ Rutkiewicz, 'W prowadzenie penicyliny', p. 163. 
40 per cent, which initially did not make them very enthusiastic about the new drug. Yet in Sicily penicillin was applied only after the wounded reached general hospitals located deep behind the front line. The Poles applied penicillin much earlier during the Italian campaign, usually just 8-10 kilometres behind the front line, at the main dressing stations. As a result, mortality in Polish units fell to 8 per cent. ${ }^{88}$ These results challenged Ogilvie's earlier view that the application of penicillin near the front line did not bring 'demonstrably better' results. ${ }^{89}$ Thanks to the early application of penicillin the Poles also had much fewer cases of amputation, and if it did become necessary to amputate a limb, the amputation was usually partial and not total..$^{90}$

After the Polish war hospitals were disbanded, Odrzywolski continued to serve in British hospitals in the Middle East for a few more years. In 1949 he moved permanently to the United Kingdom, where he first worked at a hospital for Polish veterans in Penley, east Wales, and in 1961 he moved to Leeds, where he became senior bacteriologist at the local hospital. However, he was not involved in research and development, but daily analysis of samples. In the mid-1960s he finally managed to bring from Poland his wife Irena, from whom he became separated because of the war. Janina Michniewicz and Zygmunt May married while they were still in the Middle East, and after the war settled in London. In 1952 they emigrated to Canada with their two-and-half-year-old son. In the local voters' list Zygmunt May is described as teacher, but no profession is mentioned next to the name of his wife Janina.

In the autumn of 1945 the first deliveries of penicillin - in which not only members of the armed forces but also civilians were 'swimming' began to reach Poland. Initially, they were mainly gifts from the International Red Cross, the Canadian United Polish Relief Fund and many other aid organizations. With time the main relief burden was taken over by UNRRA. In addition, from spring 1945 attempts to produce crude penicillin were also made in Poland, with researchers using the experiences from Moscow as well as strains isolated there during the war. However, the Russians themselves needed international assistance to raise

${ }^{88}$ Ibid., p. 23.

${ }^{89}$ RSA, 98 HF 36.8.9, p. 4.

${ }^{90}$ During the Bologna congress Franciszek Hipp discussed a novel method for treating gas gangrene, which he had developed with H. Szpidbaum. It consisted in injecting a penicillin solution around the focus of infection. The doctors used it in a dozen or so cases, and did not have to amputate even when the disease was very advanced. See Franciszek Hipp, 'Leczenie zgorzeli gazowej penicyliną', in Pamiętnik Zjazdu, pp. 95-96. 
the efficacy of their method to a level that would make it possible to produce a high-quality drug on a mass scale. In the end, the technology of industrial penicillin production reached Poland from the West. In 1946 UNRRA gave Poland a complete plant modelled on the facility operating at the University of Toronto. ${ }^{91}$ After all the equipment arrived in Poland, it was installed in the pre-war Ludwik Spiess \& Son factory in Tarchomin near Warsaw. A key role in the launch of the plant was played by Władysław Kuryłowicz and Tadeusz Korzybski, a microbiologist and a biochemist, who had undergone six-month training in Toronto thanks to an UNRRA scholarship.

\section{Conclusion}

As the availability of purified penicillin improved, further attempts to produce it in war hospitals in the Middle East became gradually irrelevant. Pulvertaft, a pioneer of this research, stopped them as early as in $1943 .^{92}$ So when the BMJ wrote about Odrzywolski's experiments in April 1945, from a medical point of view such activities might have seemed at least doubtful. The Polish hospital was not in a worse situation when it came to antibiotic supplies than the British hospitals, and did not have to resort to on-site production. The production of crude penicillin in laboratory conditions was cumbersome, laborious and above all extremely inefficient - when calculated in Oxford units, the amount of the active substance obtained from one culture did not even exceed the content of one standard factory-made phial.

However, in their determination to continue their penicillin research the Poles were not guided by medical considerations. As specific actions taken by the Polish government in London and the Second Corps command show, the main reason was a desire to gain experience, which could be of key significance to the creation of a modern pharmaceutical industry in post-war Poland. This is suggested by the fact that Odrzywolski was left way behind the front line and sent to England to undergo training to ex-

${ }^{91}$ Sławomir Łotysz, “A "Lasting Memorial” to the UNRRA? Implementation of the Penicillin Plant Programme in Poland, 1946-1949', ICON, 20, 2014, 2, pp. 70-91.

${ }^{92}$ We do not know when Pulvertaft stopped producing his own penicillin broth. Wyatt points to his report of June 1943 as the last one containing references to the subject, but despite having an opportunity to talk to Pulvertaft personally, he did not explain this. Wyatt, 'Robert Pulvertaft's Use of Crude Penicillin', p. 323. Yet Florey's correspondence, which - it would seem - Wyatt did not see, suggests that Pulvertaft, ignoring the opinion of the head of the Oxford laboratory that such production was pointless, continued to produce crude penicillin at least until September. See Florey to Poole, 30 September 1943, RSA, 98 HF 36.24.55. 
pand his knowledge of penicillin at its cradle - Florey's Oxford laboratory. That these were indeed the Poles' motives was indirectly suggested also by Edwards, when he said that they were preparing 'as well as possible' to help those in need in their homeland. Yet it soon turned out that at least for some of them a return to Poland was impossible. In early 1945 it became clear that after the war Poland would find itself within the Soviet sphere of influence. All plans for the post-war rebuilding of the country prepared by the Polish government in London became irrelevant, as did plans for thousands of demobilized soldiers of the Polish Armed Forces to return home.

Among those who did not return to Poland was the entire team working on penicillin at the war hospital in El-Qantara. In deciding to remain abroad and work well below their qualifications, Odrzywolski, Michniewicz and May became unable to pass on their hard won experience for the benefit of those in need in Poland. It is not the author's intention to judge the decisions of people whom the post-war situation forced to face such a dilemma. They must have heard about the persecution of many Second Corps soldiers by the communist regime. As an officer who had escaped from a Soviet prison and had been sentenced to a labour camp, Odrzywolski in particular may have feared for his safety, despite the fact that he was formally covered by the 1941 amnesty. In consequence, Witold Odrzywolski, the first Pole who obtained clinically active penicillin, vanished from history. On the other hand, those who did return to Poland included Jerzy Liedke, a pharmacist with a master's degree, who during the war first served in the Polish Army Medical Store in Scotland and then worked in one of the British penicillin factories. After the launch of the first Polish production facility in Tarchomin, he became head of its laboratory, where he 'reigned' - as was stressed at the time - as the only Pole with experience in the production of the antibiotic. ${ }^{93}$

(Translated by Anna Kijak)

\section{Summary}

The paper is an analysis of the activities of Witold Odrzywolski, who in 1944 was the first Pole to produce penicillin - in a military hospital in the Middle East. The author also outlines the status of penicillin research at the time, the problems associated with the production of penicillin, and its use in military medicine in the

93 'Pierwsza polska penicylina', Życie Warszawy, 24 July 1949, p. 5. 
final stages of the Second World war. Until mid-1944, when access to this first antibiotic was still limited, a number of doctors in military hospitals throughout the Middle East were attempting to produce their own penicillin, using Fleming's original strains of Penicillium notatum. After rudimentary purification of the resulting broth, this so-called crude penicillin was used externally, mainly to drain and wash infected wounds. During the stay of the Polish military hospital in Palestine - en route from Iraq to Egypt - the Poles obtained strains of the Penicillium mould from Jewish scientists of the Hebrew University and Weizmann Institute. In this paper Odrzywolski's achievement is shown in a broader context of the scientific, medical, military and political determinants of the period in question. In reconstructing the formation of Odrzywolski's research team, and analysing the actual production process Odrzywolski developed as well as the subsequent clinical trials of crude penicillin produced as a result, the author of the paper sheds some light on the Jewish wartime expertise in microbiology which made the Polish experiments possible. The author argues that the Poles were particularly eager to continue their penicillin research, having the post-war reconstruction of their country in mind. However, when Poland fell under Soviet control after the Yalta conference, Odrzywolski, like many other soldiers and officers of the Second Corps, chose to stay in the West. The paper is based mainly on archival resources hitherto absent from Polish historiography.

(Translated by Anna Kijak)

\section{Archives}

Archiwum Instytutu Sikorskiego i Muzeum im. Gen. W. Sikorskiego w Londynie Archives of the Sikorski Institute and Sikorski Museum in London (AIS). Archives of the Polish Academy of Sciences in Warsaw (APAN). The National Archives in London (TNA). Royal Society Archives in London (RSA). Wellcome Library Archives in London (WLA).

\section{Bibliography}

Bobińska, Anna, Pomocnicza Wojskowa Stużba Kobiet 2 Korpusu 1941-1945, Warsaw: Krupski i S-ka, 1999.

Brzeziński, Tadeusz, Służba zdrowia Polskich Sił Zbrojnych na Zachodzie 1939-1946, Wrocław: Polskie Towarzystwo Ludoznawcze, 2008.

Girling, Roy, and Geoff Hale, 'Number Five Elton Road', in Clevedon: Places and Faces, ed. Roy Campbell, Leicester: Matador, 2010, p. 63.

Hipp, Franciszek, 'Leczenie zgorzeli gazowej penicyliną', in Pamiętnik Zjazdu Polskich Lekarzy Wojskowych w Bolonii, ed. Tadeusz Sokołowski, Bari: 476 Sekcja Wydawnicza, 1946, pp. 95-96. 
Kochanowski, Jan, 'Wspomnienia z lat wojny 1939-1944: Szpital wojska polskiego nr 4 w Mossulu (Irak)', Archiwum Historii Medycyny, 32, 1969, 1, pp. 217-25.

Kruszyński, Michał, 'The State of Health of Poles Evacuated from Russia to Persia in 1942', Antemurale, 20, 1976, pp. 135-205.

Łotysz, Sławomir, 'A "Lasting Memorial” to the UNRRA? Implementation of the Penicillin Plant Programme in Poland, 1946-1949', ICON, 20, 2014, 2, pp. 70-91. Mierczyński, Eugeniusz, Wojenne wspomnienia chirurga, Warsaw: Wydawnictwo Ministersta Obrony Narodowej, 1983.

Moszumański, Zbigniew, and Zbigniew Palski, Wojsko Polskie w Iraku: Historia i współczesność, Warsaw: Wojskowe Biuro Badań Historycznych, 2003.

Ney-Krwawicz, Marek, "'Polak w Iranie” o młodych i najmłodszych uchodźcach polskich z ZSRR w Iranie w latach 1942-1944', Dzieje Najnowsze, 46, 2014, 1, pp. 85-110.

Odrzywolski, Witold, 'Przygotowywanie penicyliny i zastosowanie lecznicze penicyliny surowej’, in Pamiętnik Zjazdu Polskich Lekarzy Wojskowych w Bolonii, ed. Tadeusz Sokołowski, Bari: 476 Sekcja Wydawnicza, 1946, pp. 103-14.

Pulvertaft, Robert, 'Local Therapy of War Wounds with Penicillin', The Lancet, 18 September 1943, pp. 342-45.

Rutkiewicz, Aleksander, 'Wprowadzenie penicyliny do lecznictwa w Polskich Siłach Zbrojnych na Zachodzie’, Lekarz Wojskowy, 89, 2011, 2, pp. 161-68.

Stout, T. Duncan M., War Surgery and Medicine, Wellington: War History Branch, Department of Internal Affairs, 1954.

Śliwak, Katarzyna, 'Delegatura Ministerstwa Pracy i Opieki Społecznej w Teheranie w latach II wojny Światowej - charakterystyka działań edukacyjnych dla polskich uchodźców', Ogrody Nauki Sztuk, 5, 2015, pp. 261-68.

Wainwright, Milton, 'The History of the Therapeutic Use of Crude Penicillin', Medical History, 1987, 31, pp. 41-50.

Wojtkowiak, Stefan, Służba zdrowia w armiach zachodnich aliantów $i$ w Polskich Siłach Zbrojnych na Zachodzie, Łódź: Wojskowa Akademia Medyczna. Katedra Nauk Społecznych, 1972.

Wróbel, Janusz, Uchodźcy polscy ze Związku Sowieckiego 1942-1950, Łódź: IPN, 2003. Wyatt, Harold, 'Robert Pulvertaft's Use of Crude Penicillin in Cairo', Medical History, 1990, 34, pp. 320-26.

Biography: Dr hab. Sławomir Łotysz - associate professor at the Birkenmajer Institute for the History of Science of the Polish Academy of Sciences. He studies the social history of technology and the environmental history of Poland. For the 2017-21 term he is serving as the President of the International Committee for the History of Technology (ICOHTEC); contact: s.lotysz@gmail.com. 